\title{
Benthic and epiphytic fauna of Gastrotricha in littoral of mesotrophic lake in Łęczna-Włodawa Lakeland, Poland
}

\author{
Teresa NESTERUK
}

\author{
University of Podlasie, B. Prusa 12, 08-110 Siedlce, Poland
}

\begin{abstract}
The species composition and dominance structure of Gastrotricha living in bottom sediments and on plants: Myriophyllum sp., Ceratophyllum sp. and Elodea canadensis Michx. were studied in the littoral of the mesotrophic Lake Piaseczno from 1994 to 1996. A total of 31 Gastrotricha species altogether (22 species in bottom sediment and 20 species living on plants) were found in the habitats under study. In the benthic community there were three eudominant species (dominance $>10.0 \%$ ): Chaetonotus heteracanthus Remane, Ch. macrochaetus Zelinka and Heterolepidoderma gracile Remane, at: $13.3 \%, 15.1 \%$ and $17.1 \%$ respectively. In the epiphytic community, two species were eudominants: Heterolepidoderma macrops Kisielewski and Lepidodermella squamata Dujardin, at $27.9 \%$ and $32.4 \%$, respectively. The Gastrotricha fauna in the bottom sediments was characterised by a more even structure of dominance, which was reflected in greater biodiversity $\left(\mathrm{H}^{\prime}=2.58\right.$ compared to $\mathrm{H}^{\prime}=2.01$ for the community living on aquatic plants). Only 11 species were common to both habitats, with similarity of the two communities being as low as $17 \%$ (coefficient of homogeneity).
\end{abstract}

Key words: Freshwater Gastrotricha, bottom (benthic) and epiphytic fauna, species composition, dominance

\section{INTRODUCTION}

The majority of studies of Gastrotricha fauna of inland waters have been concerned with bottom sediments. They have helped to elucidate a number of issues connected with the ecology of Gastrotricha. The species composition and dominance relations have been assessed in different types of waters (Kisielewski 1981, 1986, Kisielewska 1982, Nesteruk 1986, Szkutnik 1986). Analyses of the vertical distribution of Gastrotricha in bottom sediments have also been carried out, and their density and biomass have been determined (Nesteruk 1991, 1996a).

Apart from bottom sediments Gastroticha also live on water plants. The ecology of these communities has not been studied yet. The only one work concerned with the epiphytic fauna (Nesteruk 2000) provided data on species and dominance composition of the taxon. More recent studies have not been concentrating on comparing Gastrotricha communities living in bottom sediments and on plants, which is the subject of this work

\section{MATERIAL AND METHODS}

The study was carried out in Lake Piaseczno ( $51^{\circ} 23^{\prime} \mathrm{N}, 23^{\circ} 02^{\prime} \mathrm{E}$, alt. $\left.170 \mathrm{~m}\right)$ situated in the Lęczna-Włodawa Lakeland (eastern Poland). Lake Piaseczno, of $38 \mathrm{~m}$ average depth and 8.5 ha surface area, is a mesotrophic reservoir without outflow. Water $\mathrm{pH}$ ranges from 5.4 to 8.2, whilst the dissolved oxygen content was found to vary during the year: from $10.2-13.2$ $\mathrm{mg} / \mathrm{l}$ (spring overturn) to $5.5-9.5 \mathrm{mg} / \mathrm{l}$ (summer stagnation) to $10.0-11.5 \mathrm{mg} / \mathrm{l}$ (autumn overturn) to $6.5-13.0 \mathrm{mg} / \mathrm{l}$ (winter). In the lake's littoral the sediment organic matter content was $52.69 \%$. The content of poorly decomposed organic matter (i.e., that part of the sediment passing through a $2.0 \mathrm{~mm}$ mesh size sieve) was 17.5\% (Nesteruk 1991). Samples were collected from April to October 1994 and from May to October 1995 and 1996. 
Seasonal changes were not taken into account, because Gastrotricha are most abundant from spring to autumn (Kisielewska 1982). The study area comprised the littoral zone of the lake with its depth from 0.8 to $5.0 \mathrm{~m}$. Aquatic plants were taken using a small anchor. The water was squeezed out from the plants into a container and 2-4 subsamples were taken (regarded as one sample) (Nesteruk 2000). The following plants were used: Myriophyllum sp., Ceratophyllum sp. and Elodea canadensis Michx. During the whole investigation period, 20 samples were obtained, with 1000 individuals of Gastrotricha identified.

Samples from bottom sediments were taken using a tubular bottom sampler (Kajak, Kacprzak \& Polkowski 1965) with a cross-section area of $10.4 \mathrm{~cm}^{2} .10 \mathrm{~cm}$ of the upper layer of the sediment in the sampler was divided into successive fractions and collected into 2-4 separate containers. These subsamples were regarded as one sample. A layer of that thickness will contain $89.3-96.5 \%$ of all Gastrotricha in the sample, $92.7 \%$ on average (Nesteruk 1991). The total number of samples from bottom sediments was 20, with 730 individuals of Gastrotricha identified. All the individuals were identified to species.

Species dominance was calculated as $D=100 \mathrm{n} / \mathrm{N}$, where $\mathrm{n}$ is the number of individuals of a given species, and $N$ is the total number of individuals. The following classes of dominance were used (Kisielewski 1981): eudominants (>10.0\%), dominants (5.01-10.0\%), subdominants $(2.01-5.0 \%)$, recedents $(1.01-2.0 \%)$ and subrecedents $(\leq 1.0 \%)$.

The Shannon-Wiener index of diversity $\left(\mathrm{H}^{\prime}\right)$ was calculated according to the formula by Shannon \& Weaver (1963)

$$
H^{\prime}=-\sum p_{i} \ln p_{i}
$$

where: $p_{i}=n_{i} / n, n_{i}$-number of i-species, $n$-total density of individuals in the zoocenosis.

Similarity of the gastrotrich fauna in different habitats was assessed using an index of homogeneity (Riedl 1963)

$$
H D=\sum_{i=1}^{s}\left(\sum_{j=1}^{k} \frac{D_{i j}}{k}\right) \frac{D_{\min _{i}}}{D_{\max _{i}}}
$$

where $D_{i j}$ is the dominance index of the $i$ th species at the $j$ th stand with a total of s species and $k$ stands.

\section{RESULTS}

In the habitats under study, 31 species of Gastrotricha belonging to the family of Chaetonotidae (Table 1) were found altogether, with 22 species found in the littoral bottom sediments of the lake and 20 species found on plants. The Gastrotricha fauna in the habitats under study differs in species composition and shows different dominance structure.

In littoral bottom sediments the following three species were clear eudominants: Heterolepidoderma gracile, Chaetonotus macrochaetus and Ch. heteracanthus, the total dominance of these species being $45.5 \%$. There were two eudominant species living on plants: Lepidodermella squamata and Heterolepidoderma macrops, whose total dominance was $60.3 \%$.

There were 11 species common to both habitats. It is necessary to mention that five species from that group belonged to the group of subrecedents in bottom sediments (dominance $\leq 1.0 \%$ ). These were: Chaetonotus parafurcatus, Ch. polyspinosus, Ch. sphagnophilus, Heterolepidoderma majus and $H$. macrops, which was a eudominant in the community living on plants (dominance $27.9 \%$ ). The value of species diversity index $\mathrm{H}^{\prime}$, including the number of species and uniformity of their dominance, was 2.58 for bottom sediments and 2.01 for plants. The faunal similarity of these two habitats was $17.14 \%$. 


\section{Discussion}

Data about the dominance of Gastrotricha in fresh waters come from Polish authors (Kisielewska \& Kisielewski 1986, Kisielewski 1986, Kisielewski \& Kisielewska 1986, Nesteruk 1986, Szkutnik 1986). Only a few of them refer to bottom sediments of lakes (Kisielewski \& Kisielewska 1986, Nesteruk 1996 a, b), while the other papers are concerned with small water basins. We know little about Gastrotricha living on plants of lakes (Nesteruk 2000). Epiphytic fauna consists of the same systematic groups as bottom fauna, but the species composition and dominance structures of both communities differ from each other (Kornijów 1988, 1989 a, b). This applies to the gastrotrich fauna under study.

Table 1. Species composition and percentage contribution of Gastrotricha living on plants and in bottom sediments in the littoral zone of Lake Piaseczno. $\mathrm{N}$ - number of individuals, $\mathrm{D}$ - percentage contribution (\%).

\begin{tabular}{|c|c|c|c|c|c|}
\hline \multirow{2}{*}{ No. } & \multirow{2}{*}{ Species } & \multicolumn{2}{|c|}{ Sediment bottom } & \multicolumn{2}{|c|}{ Plants } \\
\hline & & $\mathrm{N}$ & $\mathrm{D}$ & $\mathrm{N}$ & D \\
\hline 1 & Chaetonotus acanthodes Stokes, 1887 & 10 & 1.4 & & \\
\hline 2 & Ch. brevisetosus Roszczak, 1935 & - & - & -4 & 0.4 \\
\hline 3 & Ch. brevispinosus Zelinka, 1989 & - & - & -8 & 0.8 \\
\hline 4 & Ch. disiunctus Greuter, 1917 & 39 & 5.3 & - & - \\
\hline 5 & Ch. heideri Brehm, 1917 & 25 & 3.4 & 70 & 7.0 \\
\hline 6 & Ch. heteracanthus Remane, 1927 & 97 & 13.3 & & \\
\hline 7 & Ch. hystrix Mečnikow, 1865 & - & - & 16 & 1.6 \\
\hline 8 & Ch. insigniformis Greuter, 1917 & - & - & 8 & 0.8 \\
\hline 9 & Ch. macrochaetus Zelinka, 1889 & 110 & 15.1 & 66 & 6.6 \\
\hline 10 & Ch. macrolepidotus Remane, 1927 & 12 & 1.6 & - & - \\
\hline 11 & Ch. maximus Ehrenberg, 1830 & 15 & 2.1 & & \\
\hline 12 & Ch. octonarius Stokes, 1887 & - & - & 13 & 1.3 \\
\hline 13 & Ch. oculifer Kisielewski, 1981 & 38 & 5.2 & 8 & 0.8 \\
\hline 14 & Ch. ophiogaster Remane, 1927 & 18 & 2.5 & - & - \\
\hline 15 & Ch. parafurcatus Nesteruk, 1991 & 3 & 0.4 & 4 & 0.4 \\
\hline 16 & Ch. persetosus Zelinka, 1889 & - & - & 12 & 1.2 \\
\hline 17 & Ch. polyspinosus Greuter, 1917 & 6 & 0.8 & 25 & 2.5 \\
\hline 18 & Ch. poznaniensis Kisielewski, 1981 & 4 & 0.5 & - & - \\
\hline 19 & Ch. similis Zelinka, 1889 & 64 & 8.8 & 12 & 1.2 \\
\hline 20 & Ch. sphagnophilus Kisielewski, 1981 & 4 & 0.5 & 45 & 4.5 \\
\hline 21 & Ch. spinulosus Stokes, 1887 & - & - & 12 & 1.2 \\
\hline 22 & Chaetonotus sp. & 3 & 0.4 & 16 & 1.6 \\
\hline 23 & Heterolepidoderma gracile Remane, 1927 & 125 & 17.1 & 12 & 1.2 \\
\hline 24 & H.macrops Kisielewski, 1981 & 5 & 0.7 & 279 & 27.9 \\
\hline 25 & H. majus Remane, 1927 & 6 & 0.8 & 37 & 3.7 \\
\hline 26 & Heterolepidoderma sp. & 2 & 0.3 & 9 & 0.9 \\
\hline 27 & Lepidodermella minor (Remane, 1935) & 69 & 9.4 & 12 & 1.2 \\
\hline 28 & L. squamata (Dujardin, 1841). & 15 & 2.1 & 324 & 32.4 \\
\hline 29 & Aspidiophorus oculifer Kisielewski, 1981 & 13 & 1.8 & - & - \\
\hline 30 & A. squamulosus Roszczak, 1936 & - & - & - & - \\
\hline 31 & Ichthydium forficula Remane, 1927 & 18 & 2.5 & & \\
\hline 32 & I. palustre Kisielewski, 1981 & - & - & - & - \\
\hline 33 & I. podura (Müller, 1773) & - & - & -4 & 0.4 \\
\hline \multirow[t]{4}{*}{34} & Ichthydium sp. & 29 & 4.0 & 4 & 0.4 \\
\hline & Total & 730 & 100.0 & 1000 & 100.0 \\
\hline & $\mathrm{H}^{\prime}$ & \multicolumn{2}{|c|}{2.58} & \multicolumn{2}{|c|}{2.01} \\
\hline & $\mathrm{HD}$ & & & & \\
\hline
\end{tabular}


The community of Gastrotricha living on plants is dominated by a small number of species. The group of clear eudominants and dominants in this habitat is made up of: $C h$. macrochaetus, Chaetonotus heideri, Heterolepidoderma macrops and Lepidodermella squamata, with dominance indices of $6.6 \%, 7.0 \%, 27.9 \%$ and $32.4 \%$ respectively. It is important to underline that $H$. macrops has been found to stay mainly on aquatic plants (Kisielewski 1998). Thus, it is not surprising that its dominance index in bottom sediments is only $0.7 \%$ and is more than 40 times lower than its dominance index in the community living on plants. Gastrotrich fauna living on plants, as well as periphyton Nematoda fauna is distinctly dominated by a few species. Among periphyton Nematoda the most common dominants are three species: Chiromadorina bioculata Schultze, Punctodora ratzeburgensis Linstow and Chromadorina viridis Linstow (Prejs 1988).

The group of eudominants and dominants in littoral bottom sediments of the lake under study consists of seven species: Ch. oculifer, Ch. disiunctus, Ch. similis, L. squamata, Ch. heteracanthus, $C h$. macrochaetus and $H$. gracile, the percentage contributions of these species being: 5.2, 5.3, 8.8, 9.4, 13.3, 15.1 and $17.1 \%$ respectively. Ch. disiunctus and $C h$. heteracanthus were not recorded as living on plants, Ch. similis, Ch. oculifer and $H$. gracile belong to recedents or subrecedents in this habitat. Of note is the species $H$. gracile, living in slime and more rarely among Sphagnum or other mosses (Kisielewski 1981). It has been recorded in bottom sediments of the lake for the first time by Nesteruk (1996 b), where it belonged to the group of eudominants (dominance 14.3\%). In the community living on plants in Lake Piaseczno, it belongs to the group of subrecedents, with a dominance index of $1.2 \%$.

Some of the Gastrotricha species find the most favourable living conditions both in bottom sediments and on plants. These species are: Ch. macrochaetus and L. squamata. The former species was once considered to be mainly a peat bog species (Kisielewski 1981), in the bottom sediments of the lake it belongs to eudominants (dominance $15.1 \%$ ), and on plants it belongs to dominants (dominance 6.6\%). Earlier studies (Nesteruk 1996 b) show that it is a eurytopic species and common in all types of lakes. It lives in slime and on water plants, and also in sand (Kisielewski 1998). L. squamata is a lacustrine species. It is abundant in mountain lakes, littoral lakes and in lakes with different trophic conditions (Nesteruk 1996 b). It is found in all types of substrate: in slime, on plants and in sand. In the bottom sediments of the littoral of the lake under study it belongs to dominants (dominance 9.4\%), and on plants it belongs to eudominants (dominance $32.4 \%$ ).

Four of the species identified in the lake under study are generally numerous and very numerous in bottom sediments, but they were not found on plants. These are: $C h$. heteracanthus, Ch. disiunctus, Ichthydium forficula and I. palustre. The first of them belongs to eudominants, the second to dominants, and the third and fourth to subdominants.

$C h$. disiunctus and I. forficula are common eurytopic species abundant in peat bogs, strongly eutrophicated basins and lakes of different fertility levels. Ch. disiunctus lives mainly in slime, more rarely among decaying leaves and in sand, I. forficula lives mainly among peatmosses and in slime, and $I$. palustre only in slime. Ch. heteracanthus has only been found in slime of the fertile ponds, peaty basins and in lakes. It has also been found in the bottom sediments of the deep profundal of a mesotrophic lake (Nesteruk 1996 b). It should be emphasized that no species of the genus Aspidiophorus have been found on plants.

From the given above analysis of abundance and dominance of individual species it is clear that there are differences between the composition of epiphytic and benthic fauna. There may be different factors influencing the dominance structure of both communities. One of them is waves, which wash out the animals and help species to spread. The dependence of the dominance structure on waves has been noticed in periphyton with reference to Nematoda (Pieczyńska 1964). Hanson (1990) shows the possibility of migration of representatives of both 
habitats. It is certainly possible, but we should remember that individual species prefer one or another type of substratum in which they find optimum living conditions. Differences in species composition of Gastrotricha in the habitats under study, which have the same number of abundant species, testify to this thesis. Typical representatives of bottom sediments are not found on plants or belong to recedents there. Only 11 species are common to both habitats, and fauna similarity, calculated according to the homogeneity coefficient (Riedl 1963), is 17.14\%. Kornijów (1992) working on Chironomidae, described on the example of one species the migration of epiphytic fauna to bottom sediments and back in spring connected with autumn macrophytes dying off. We may presume that this type of migration is also seen in gastrotrich fauna.

Comparison of the values of the synthetic index $\left(\mathrm{H}^{\prime}\right)$, which takes into account the number of species identified and uniformity of their dominance, shows less diversity in the community living on lake plants than in that living in bottom sediments. It is important to underline that in both habitats the values of $\mathrm{H}^{\prime}$ are high, distinctly below the values obtained for some alder carrs $\left(\mathrm{H}^{\prime}=2.95\right)$ (Kisielewska \& Kisielewski 1986), basins with a rushes vegetation $\left(\mathrm{H}^{\prime}=2.98\right)$ (Szkutnik 1986) and basins with the Hydrocharitetum morsus-ranae assembly $\left(\mathrm{H}^{\prime}=2.95\right)$ (Kisielewski 1986).

\section{REFERENCES}

HANSON J.M. 1990. Macroinvertebrate size - distribution of two contrasting freshwater macrophyte communities. Freshw. Biol. 24: 481-491.

KAJAK Z., KACPRZAK K \& POlKowski R. 1965. Tubular bottom sampler. Ekol. Pol., Warszawa, B, 11: $159-165$.

KISIELEWSKA G. 1982. Gastrotricha of two complexes of peat hags near Siedlce. Fragm. faun. 27: 39-57.

KISIELEWSKA G \& KISIELEWSKI J. 1986. Freshwater Gastrotricha of Poland. III. Gastrotricha from the Białowieża Forest and the Białowieża Glade. Fragm. faun. 30: 195-213.

KISIELEWSKI J. 1981. Gastrotricha from raised and transitional peat bogs in Poland. Monogr. Fauny Pol. 11 : 143 pp.

KISIELEWSKI J. 1986. Freshwater Gastrotricha of Poland. VII. Gastrotricha of extremely eutrophicated water bodies. Fragm. faun. 30: 267-295.

KISIELEWSKI J. 1998. Brzuchorzeski (Gastrotricha). Fauna Słodkow. Polski 31: 157 pp.

KISIELEWSKI J \& KISIELEWSKA G. 1986. Freshwater Gastrotricha of Poland. I. Gastrotricha from the Tatra and Karkonosze Mountains. Fragm. faun. 30: 157-182.

KORNIJÓw R. 1988. Distribution of the zoobenthos in the littoral of two trophically different lakes. Pol. Arch. Hydrobiol. 35: 185-197.

KORNIJÓw R. 1989 a. Macrofauna of elodeids of two lakes of different trophy. I. Relationships between plants and structure of fauna colonizing them. Ekol. Pol., Warszawa, 37: $31-48$.

KORNIJÓW R. 1989 b. Seasonal changes in the macrofauna living on submerged in the two lakes of different trophy. Arch. Hydrobiol. 117: 49-60.

KORNIJÓw R. 1992. Seasonal migration by larvae of an epiphytic chironomid. Fresh.Biol. 27: 85-89.

Nesteruk T. 1986. Freshwater gastrotricha of Poland. IV. Gastrotricha from fish ponds in the vicinity of Siedlce. Fragm. faun. 30: 215-233.

NESTERUK T. 1991. Vertical distribution of Gastrotricha in organic bottom sediment of inland water bodies. Acta Hydrobiol. 33: 253-264.

NESTERUK T. 1996 a. Density and biomass of Gastrotricha in sediments of different types of standing waters. Hydrobiologia 324: 205-208.

NESTERUK T. 1996 b. Species composition and dominance structure of gastrotrich (Gastrotricha) assemblages in water bodies of different trophic status. Hydrobiologia 339: 141-148.

NESTERUK T. 2000 Epiphytic Gastrotricha - species composition and dominance. Acta Hydrobiol. 42: 53-57.

PIECZYŃSKA E. 1964. Investigations on colonization of new substrates by nematodes (Nematoda) and some other periphyton organisms. Ekol. Pol., Warszawa, 12: 186-234.

PREJS K. 1988. Ecology of freshwater nemtodes. Wiad. Ekol. 34: 3-29. [ in Polish with English summary].

RiEDL R. 1963. Probleme und Methoden der Erforschung des litoralen Benthos. Verh. Dtsch. Zool. Suppl. 26: 505-567.

SHANNON C. E.\& WEAVER W. 1963. The mathematical theory of communication. University of Illinois Press, Urbana, $117 \mathrm{pp}$.

SZKUTNIK A. 1986. Freshwater Gastrotricha of Poland. VI. Gastrotricha of small astatic water bodies with rush vegetation. Fragm. faun. 30: 251-266. 


\section{STRESZCZENIE}

\section{[Fauna bentosowa i epifityczna brzuchorzęsków (Gastrotricha) w litoralu jeziora mezotroficznego]}

Celem pracy było porównanie fauny dennej i naroślinnej brzuchorzęsków na podstawie ich składu gatunkowego i stosunków dominacji. Badania prowadzono od kwietnia do października 1994 roku i od maja do października 1995 i 1996 roku w litoralu mezotroficznego jeziora Piaseczno położonego na Pojezierzu Łęczyńsko-Włodawskim. Analizą objęto osady denne litoralu jeziora i roślinność zanurzoną, którą stanowiły: Myriophyllum sp., Ceratophyllum sp. i Elodea canadensis Michx. W obu środowiskach w każdym roku pobrano po 20 próbek na głębokości 0,8-5,0 m. Ogółem stwierdzono 31 gatunków brzuchorzęsków (22 w osadach dennych i 20 na roślinności). Eudominantami (dominacja $>10,0 \%$ ) w osadzie dennym były trzy gatunki: Heterolepidoderma gracile Remane, Chaetonotus macrochaetus Zelinka, Ch. heteracanthus Remane, z dominacją odpowiednio: 17.1\%, 15.1\% i 13.3\%. Na roślinności zanurzonej eudominantami były dwa gatunki: Lepidodermella squamata i Dujardin $H$. macrops Kisielewski z dominacją: 32.4\% i 27.9\%.

Fauna brzuchorzęsków w osadach dennych charakteryzowała się bardziej wyrównaną strukturą dominacji, co znalazło odbicie w większej różnorodności $\left(H^{\prime}=2,58\right.$ wobec $H^{\prime}=2,01$ dla roślinności zanurzonej). Dla obu środowisk wyodrębniono tylko 11 gatunków wspólnych, a podobieństwo fauny Gastrotricha wyliczone na podstawie współczynnika homogeniczności Riedla (1963) wynosi zaledwie $17.14 \%$. 